\title{
Game of Organizational Politics Leading to Turnover Intention
}

\author{
Amir Ali Khushk ${ }^{1}$, Zhang Zengtian ${ }^{2}$, Nasir Aman ${ }^{3}$ \\ ${ }^{1}$ University of Science and Technology China \\ https://orcid.org/0000-0002-1895-9821 \\ amir65378@gmail.com \\ ${ }^{2}$ University of Science and Technology China \\ zhzt@ustc.edu.cn \\ ${ }^{3}$ University of Science and Technology China \\ nasiraman160@gmail.com
}

\begin{tabular}{|c|c|}
\hline Article Info & Abstract \\
\hline $\begin{array}{l}\text { Article history: } \\
\text { Received:23 March } 2020 \\
\text { Revised: } 27 \text { April } 2021 \\
\text { Accepted: } 27 \text { April } 2021\end{array}$ & $\begin{array}{l}\text { Purpose: This study investigated the role of job pressure in the relationship } \\
\text { between organizational politics and turnover intent among faculty members in } \\
\text { universities in Pakistan. This study also assessed the impact of politics at the } \\
\text { workplace among faculty members in the universities of Pakistan } \\
\text { Methodology/Approach/Design: This study was performed in Pakistan, using }\end{array}$ \\
\hline $\begin{array}{l}\text { Keywords: } \\
\text { Organizational Politics, } \\
\text { Turnover Intention, Job Stress, } \\
\text { University, }\end{array}$ & $\begin{array}{l}\text { primary data collected through a questionnaire. The total number of } \\
\text { participants was } 270 \text {. A convenient sampling technique was employed for } \\
\text { selecting the sample. The majority of the respondents were from the Punjab } \\
\text { province followed by Sindh province, KPK, and Baluchistan. Two independent } \\
\text { variables perceived organizational politics and job stress, and one dependent }\end{array}$ \\
\hline JEL: L22, P11, O31,D32 & $\begin{array}{l}\text { variable, Turnover intention, were considered for this research. Reliability } \\
\text { analysis and multiple regressions were used as data analysis in this study. }\end{array}$ \\
\hline Paper Type : & Results: The independent variable i:e Perceived organizational politics \\
\hline Research Article & $\begin{array}{l}\text { selected for the research is found to be positive and significant with relation to } \\
\text { the dependent variable i:e Turnover Intention. This means the management }\end{array}$ \\
\hline Corresponding Author: & $\begin{array}{l}\text { can predict the turnover intention of employees by taking into consideration } \\
\text { the variables such as organizational politics, and mediating variable- job } \\
\text { stress. }\end{array}$ \\
\hline $\begin{array}{l}\text { Zhang Zengtian } \\
\text { Email: }\end{array}$ & $\begin{array}{l}\text { Practical Implications: The practical implication of this research will help } \\
\text { the management to control the effects of politics in the organization on the job } \\
\text { of faculty members and design policies and training to engage and deal with }\end{array}$ \\
\hline & $\begin{array}{l}\text { the stress caused by organizational politics and retain the employees and } \\
\text { decrease the turnover rate in universities. }\end{array}$ \\
\hline & $\begin{array}{l}\text { Originality/Value: This is one of the few studies that evaluate the effect of } \\
\text { politics on turnover intention due to job stress in the context of Universities. } \\
\text { This is important for both academia and scholars alike. Numerous studies } \\
\text { recently paid attention to the impact of work politics on turnover intent. Thus, } \\
\text { this analysis would aggregate the variable of past studies along with job } \\
\text { stress, to check the effect on turnover intention. }\end{array}$ \\
\hline
\end{tabular}

\section{Introduction}

Organizations have been facing the problem of employee turnover for decades, but still, this issue frustrates the management within organizations as businesses spend a huge amount of money in recruiting the right person and training them but are unable to retain them. According to a report by the (Alliance For Excellent Education, 2014) significant percentage of teachers in the United States either relocate or leave each year. Attrition in this field is especially high among new teachers, with far more than 40 to 50 percent leaving after 5 years. 
It's understandable, provided that teachers are usually expected to work 55 to 60 hours per week in a work that can have a detrimental influence on teachers' enthusiastic, emotional, and, physical level. Employees are considered to be one of the most important factors in an organization, hence corporate politics can have a significant influence on employees' morale. This research aims to examine the relationship between organizational politics and turnover intention. If stressed out, some employees would make the audacious decision to quit his or her job. Turnover is a big challenge that nearly every organization faces due to high spending on recruitment, training, and retention of staff. According to Liu \& Onwuegbuzie (2012), the potential reasons for the Chinese teachers' intention to leave include a high degree of stress, low salary, insufficient rest and vacations, a high workload, and participant conduct. The results of the study indicated that 40.4 percent of the teaching staff stated that, if the possibility occurs, they would potentially or quit the education sector for another career (Liu \& Onwuegbuzie, 2012).In another study, Daskin \& Tezer(2012) investigated the effects of lack of resources, unfairness, and managerial commitment and the influence on workers' turnover intentions in Cyprus hotels. The findings of the study showed that insufficient capital and nepotism are critical aspects for the analysis of issues related to organizational politics (Daskin \& Tezer, 2012).

Organizational politics is described as an activity that assists employees within an organization in achieving their goals without going through the appropriate channels. Political activity is reflected via the essence of employee understanding of what politics is (Andrews \& Kacmar, 2001). Three features of assumed organizational politics help to combine this framework with wider job tension. Firstly, it has been defined as an internally observed phenomenon rather than as a particular function of the work environment, as events, individuals, and actions are viewed and understood in various ways by different individuals. Second, complexity and instability are essential to understand the mechanisms and consequences of assumed politics. Third, it can be viewed as either a threat or an opportunity (Ferris et al., 2002).

Previous research focused on a theoretical path-driven analysis that distinguishes the causes of job financial support, work tension, burnout, and desire to quit a job between age categories. The findings of many studies suggest that the mechanisms of work pressure, fatigue, and desire to leave (Dohrmann et al., 2019; Oldenburg et al., 2013; Techera, 2017). Working together or social capital factors have been more prominent in defending elderly employees from workplace pressures relative to unskilled employees (Boyas et al., 2012). In this study, the results of two job aspects, nature of work and a set of skills on stress and attrition intent of elderly and young employees were compared. This research study broadens previous studies by considering an additional independent variable i.e, perceived organizational politics and job stress, which examine the impact on the dependent variable i.e, Turnover Intention. The management needs to understand and control the organizational politics and manage the job stress to retain their workforces for a longer time. This research is theoretically supported by the perception organizational politics theory and JD-R theory which proposed a logical perspective to help understand the impact of institutional and behavioral fairness on the intentions of turnover. 


\section{Literature Review}

\section{Perceived Organizational Politics and Turnover Intention}

Several studies focus on the effects on perceptions of organizational politics, including centralization of power, formalization, bureaucratic level, and the extent of command. Centralized control, the degree to which power and authority are clustered in the top ranks of the corporation, is believed to affect expectations of corporate policy since it can promote an assumed lack of autonomy. Since it can encourage total absence of power and high levels of political behavior aimed at manipulating critical decisions. This kind of political conduct tends to establish an unsafe and troublesome workplace, lessens hierarchical productivity and viability, and has incredibly unsafe impacts upon workers (Atinc et al., 2018). Perception of organizational politics and employee behaviors offers clear information to validate the belief that perceptions of organizational policy are linked to decreased work satisfaction, organizational engagement, turnover intentions, job efficiency, and enhanced mental pressure (Chang et al., 2009). On another side, managerial assistance is adversely correlated to organizational politics. Empirical findings have shown that even the views of frontline decision managers have had a significant impact on their voluntary turnover. Research predicts politics in organization, desire to leave, and organizational engagement to the productivity and competitiveness of academic personnel. The analysis reveals that the predictive factors together and independently contributed greatly to the estimation of the criteria factor. But there were strong and favourable associations between corporate politics and intention to leave. Therefore, politics can have an adverse and detrimental effect on corporate competitiveness by the performance and effectiveness of workers(Gbadamosi \& Nwosu, 2011).

Earlier research has found that representative turnover is inconvenient for both people and organizations. Because the goal of attrition in the work environment is hindering, a variety of factors have been suggested, this even more likely to understand the reasons why members may want to abandon their organizations. This research explores the interaction between perceived organizational politics, organizational human resource policies, and the attrition of registered nurses in Nigeria. The finding revealed that both management trust and established human resource policies were strongly and adversely linked to the intention to leave the organization (Abubakar et al., 2014). The views of the corporate practices held by the representative of various organizations and how they influence their organizational fairness and judgment on the recruitment of workers. As findings of the studies, it was observed that corporate regulation had a substantial influence on the perceived organizational fairness and decision to leave (Kaya et al., 2016)

\section{Organizational Politics and Job Stress}

Organizational politic is defined as the use of force that requires exercises that are being attempted to achieve one's proposed outcomes or advantages (Gull \& Zaidi, 2012). In the event of negative perception, perceptions of ambiguous circumstances, bad job results, and loss of trust

Copyright (C) 2021, Journal of Advanced Research in Economics and Administrative Sciences (JAREAS), Under a 
and confidence among staff, as they are not sure of what meaning they may have of their activities, are uncertain about their external actions, and are not sure how to react (Meisler \& Vigoda-Gadot, 2014). Politics in businesses is viewed as a consequence of the actions of managers and co-workers and corporate policies and procedures. His model on organizational politics perception clearly defines how politics in organizations have used a source of stress. Another interesting feature of his study found that the association between stress and politics is the core function of ambiguity. Lack of certainty is one of the fundamental circumstances through which political activity takes place and is a significant influencer in developing a conception of politics. The association between organizational politics and stress has been verified by comprehensive studies and even some various theoretical constructs, such as Job Demands-Resources (JD-R) Theory, Appraisal theory, Effort-Reward theory of imbalance. Until it was studied by(Ferris et al., 1996)no one knew about the correlation and impact between politics and stress

Work stress is described as greatly harmful and energizing reactions that arise when the demands of the occupation do not meet the expertise and needs of the workers. This sets an immense test for the intellectual and actual well-being of the workers. Stressed workers are less adventurous, get-together, and induced than those who in any case affect their association. Subsequently, these people gave the nation enormous misfortune (Ullah \& Ahmad, 2018). Research on perceived organizational politics, engagement, and stress supports the dimension of the data and legitimacy of a current generation of metrics of organizational politics based on generic expectations of these and another misuse of interactions, capital, credibility, judgments, and sources of information. The findings also revealed an important and clear correlation regarding politics within organizations and stress (Landells \& Albrecht, 2019).

Another study on nurses in Filipino also supports the past studies. The views of organizational politics of Filipino nurses are less than those in other global research. There was a close correlation between the expectations of workplace politics and the other job outcomes, such as work stress (Labrague et al., 2017). The 3-way significant influence of perceived organizational support has been established, whereas the influence of humans on smartphone usage at work and stress has been confirmed. Explicitly, in a hostile political workplace, the detrimental impact of smartphone usage after work, which induces job tension, was observed to be mitigated when organizational support was high. Even then, in a supportive political setting, additional support from bosses has clearly been shown to raise the detrimental effect of job-related smartphone use after work, whereas good support groups have decreased the adverse influence of task-related use of smartphones after working hours (Park et al., 2020). Lately, several scholars have focused on the optimistic side of the politics in the organization i.e., giving the premise of the upper hand, create positive political abilities, which cause a successful political circumstance which doesn't influence by bad form, injustice, and so forth, serving the destinations of the association and the vision and create collaboration and certainty (Karen, 2015). Organizational politics has arisen as a field of great concern to a wider population, extending from social psychology researchers to the general public. A variety of previous reports have highlighted the problem of

Copyright (C) 2021, Journal of Advanced Research in Economics and Administrative Sciences (JAREAS), Under a 
office politics. Over the past decades, the attention has been on the organization's political atmosphere and the workers' discontent. For this reason, both management and researchers have shown a keen interest in understanding the sources of employee discontent from a particular viewpoint. However, limited research has examined the role of organizational politics on turnover intentions.

\section{Stress and Turnover Intention}

Research proves a positive relationship between organizational politics and stress. The findings of the research indicate that stress could be a positive thing or a risk, based on the level of pressure experienced by the person. Besides, politics in an organization may serve as a possible job source of stress for workers who can contribute to work anxiety. Workplace politics is not a passing occurrence, but a constant practice that involves and exists within the enterprise (Rasid et al., 2013). Based on the theory of socio-emotional selection criteria and rationale optimization techniques with compensation principle. We believed that the diversity of tasks would result in improved results for younger staff, while the range of skills would contribute towards more positive results for older employees. All over 2 samples including time-consuming models, Greater work variability was shown to lead to fewer task fatigue and lower turnover expectations in younger employees compared to older employees. On the other hand, appropriate skills diversity has resulted in lower turnover intentions for older workers than among younger employees (Zaniboni et al., 2013). In this study, the meta-analysis findings show the association among expectations of corporate strategy (POP) and attitudinal, psychological, and behavioral factors. Of the variables analyzed, POP is more closely linked to trust and interpersonal justice, but it also linked to several other criteria, including a supportive link with tension and intention to leave (Bedi \& Schat, 2013). Confirmatory and exploratory factor analyzes suggest nine causes of stress in nurses. The volume of work is by far the most common stressor. Besides that, the workload was adversely correlated to worker satisfaction and better quality of service. The amount of work and dispute with nurses were strongly associated with the desire to leave (Bautista et al., 2020). Another clinical nursing research in South Korea on variables influencing the aim of nurses' workers to make a turnover focusing on a structural equation model.

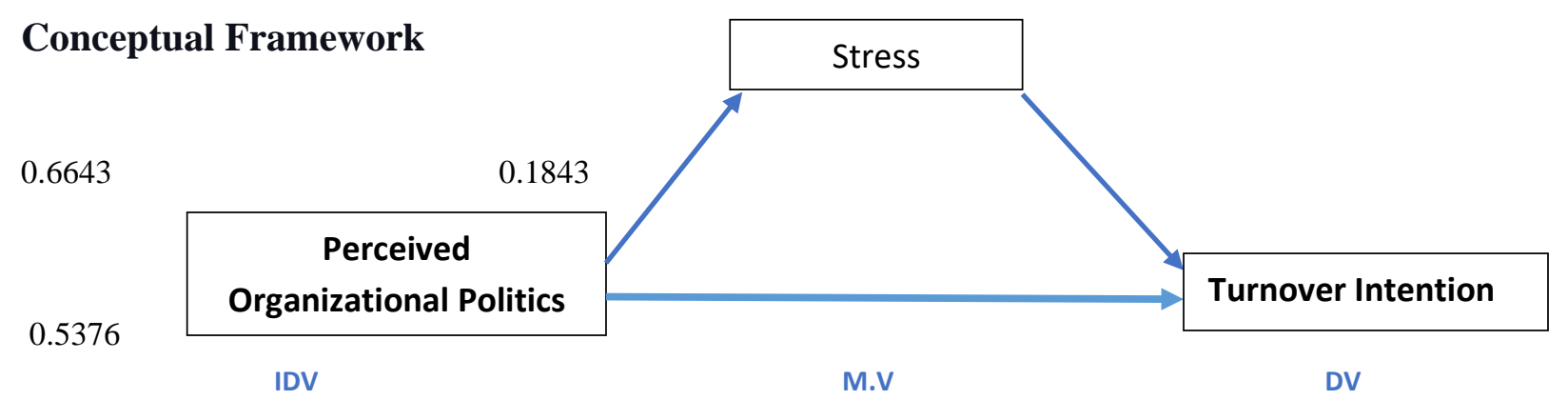

Copyright (C) 2021, Journal of Advanced Research in Economics and Administrative Sciences (JAREAS), Under a 


\section{Methodology and Procedures}

\section{Research Design}

Quantitative analysis methods were used in this research. The aim of the assumption is that a structured response is identified in the survey and that this research work has been carried out systematically. Also, this analysis approach enables researchers to achieve reliable, impartial results. The descriptive analysis is used to explain the relationship between the variables of concern in this study. It can also have a specific circumstance; include a clarification of what is happening and procedures, plus triggers and effects.

\section{Data Collection}

The primary data source for the analysis is the compilation of research information from the respondents. A structured questionnaire was developed as a data collection tool. It was distributed online to the faculty working in the universities of Pakistan, and data was obtained directly from the respondents.

\section{Research Instrument}

The source of the research is primary data; hence data were collected from respondents with the support of the 5-point Likert scale. The questionnaire consists of 15 questions based on the 5point Likert scale. The Likert scale is calculated based on 1-Strongly Disagree, 2-Disagree, 3) Neutral, 4) Agree, and 5) Strongly Agree. The nature of the questionnaire for this research is based on the previous literature and theoretical framework in the field. To measure the impact of perceived organizational politics, the questionnaire statements were adapted from (Kacmar \& Ferris, 1991).To check the impact of stress, the questionnaire statements were adapted from (Cohen, S., Kamarck, T., Mermelstein, 1983). Moreover, to determine the influence of turnover intention, the questionnaire statements were adapted from Moore(2009).

\section{Population and Sampling}

The population of this research study includes university teachers in Pakistan. The sample was specifically drawn from the Punjab province, Sindh province, KPK, and Baluchistan. The objective of this study is to analyze the causes of employee Turnover Intention in Universities, Pakistan. Hence, the population and sample are comprised of faculty members of universities. Because of several restrictions, such as timeframe, location as well as funding, a non-probability sample called the convenience sampling technique was employed.

Table.1 Universities List

\begin{tabular}{|l|l|l|c|}
\hline Sr.no & \multicolumn{1}{|c|}{ Universities Names } & Province & $\begin{array}{l}\text { Percentage } \\
\mathbf{\%}\end{array}$ \\
\hline 1. & University of Central Punjab, Lahore & Punjab & \multirow{4}{*}{$\mathbf{4 8 . 5 2 \%}$} \\
\cline { 1 - 3 } 2. & Institute of Management Science, Lahore & Punjab & \\
\cline { 1 - 3 }
\end{tabular}

Copyright (C) 2021, Journal of Advanced Research in Economics and Administrative Sciences (JAREAS), Under a 


\begin{tabular}{|c|c|c|c|}
\hline 3. & Lahore University of Management Science & Punjab & \\
\hline 4. & SZABIST University Karachi \& Hyderabad & Sindh & \multirow[t]{3}{*}{$28.52 \%$} \\
\hline 5. & IBA University Karachi \& Sukker & Sindh & \\
\hline 6. & IQRA University Karachi & Sindh & \\
\hline 7. & University of Peshawar & KPK & \multirow[t]{2}{*}{$17.04 \%$} \\
\hline 8. & Abasyn University & KPK & \\
\hline 9. & $\begin{array}{l}\text { Balochistan University of Information Technology, } \\
\text { Engineering and Management Sciences }\end{array}$ & Balochistan & $5.93 \%$ \\
\hline
\end{tabular}

Source: Authors

\section{Research Variables}

Variable is classified as a term that may have various numerical values. A variable that is influenced by another factor implies that it is a function of some other variable that is considered the dependent variable. On the other hand, the variable that causes the shift in the other variable is considered an independent variable (Kothari \& Gaurav 2014). This research also highlights the relation between two variables. Table 2 highlights the dependent and independent variables and along with statistical techniques.

Table 2Variables and Techniques

\begin{tabular}{|l|l|c|c|}
\hline S.NO & \multicolumn{1}{|c|}{ Variables } & Techniques \\
\hline & \multicolumn{1}{|c|}{ IDV } & DV & \\
\hline $\mathbf{1}$ & Perceived Organizational Politics & \multirow{2}{*}{ Turnover Intention } & $\begin{array}{c}\text { Reliability Analysis and } \\
\text { Multiple regression } \\
\text { analysis }\end{array}$ \\
\hline $\mathbf{2}$ & Job Stress & & \begin{tabular}{c} 
analy \\
\hline
\end{tabular}
\end{tabular}

Source: Authors

\section{Demographic Distribution(Gender, Age, Education, Employment and Province)}

Figure 2 shows that $30 \%$ of the 270 respondents in this study were females, while $70 \%$ of the respondents were males. Figure 2 shows that out of 270 respondents of this study, $24.07 \%$ belong to the age group of $26-29,27.04 \%$ belong to the age group of $30-33$ and $48.89 \%$ belong to the age group of 34 and above. Figure 3 highlights that $24.44 \%$ of the respondents are Ph.D. Scholars, $20.37 \%$ of the respondents are Graduates and $55.19 \%$ of the participants are Post Graduate Students. Figure 4 shows that the highest numbers of participants in our research are from the Management Science department 30.74\%, followed by Education and Science department $22.22 \%$ then the Computer Science department, $10.37 \%$ from Mechatronics Engineering and $8.15 \%$ from Media science and life science. Figure 5 most of the respondents in the study were from Punjab province $48.52 \%$, followed by Sindh Province $28.52 \%$, then KPK with $17.04 \%$ respondents and $5.93 \%$ from Balochistan.

Copyright (C) 2021, Journal of Advanced Research in Economics and Administrative Sciences (JAREAS), Under a 


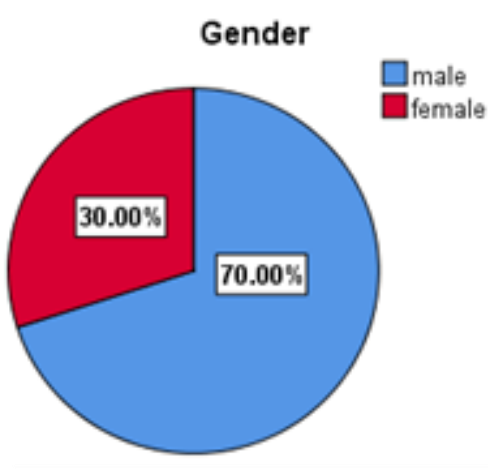

Figure 1 Gender

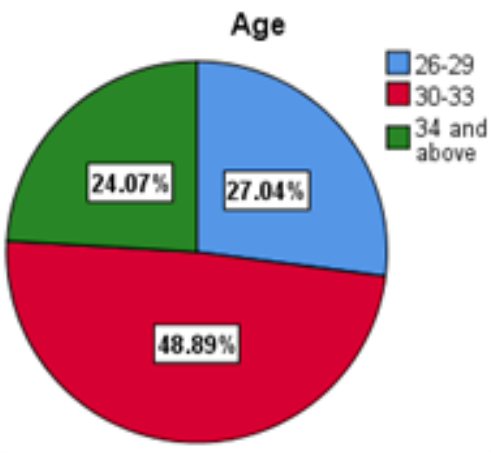

Figure 2 Age

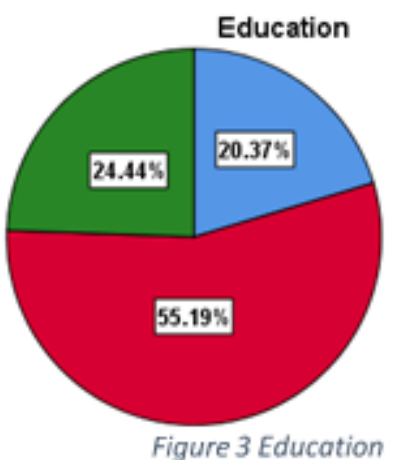

Province

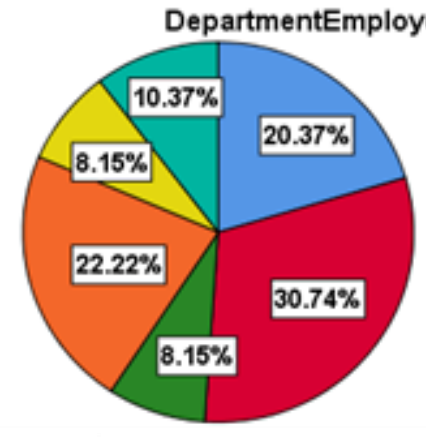

Figure 4 Employment

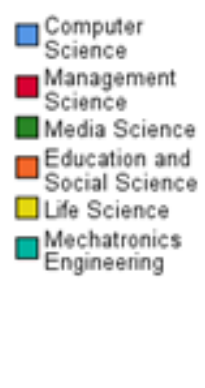

$\square$ Science
$\square$ Management
Science
$\square$ Media Scienc
$\square$ Education and
Social Scienc
$\square$ Life Science
$\square$ Mechatronics

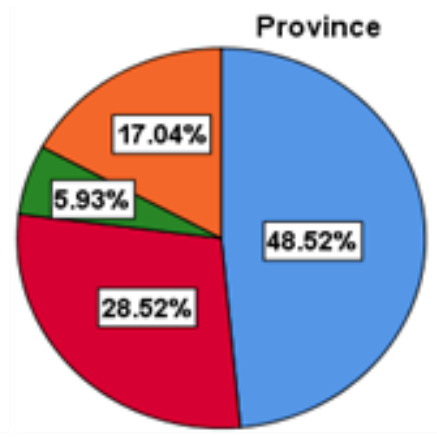

Figure 5 Provinces a Graduate

Post Graduate

Student

uph.D. Scholat

4. Results and Discussion

Table 3Reliability Statistics

\begin{tabular}{|l|c|c|c|}
\hline Variables & Cronbach's Alpha & No: of Items & Interpretation \\
\cline { 1 - 1 } Perceived Organizational Politics & \multirow{2}{*}{$\mathbf{8 6 1}$} & $\mathbf{2 6}$ & Excellent \\
\cline { 1 - 1 } Job Stress & & & \\
\cline { 1 - 1 } Turnover Intention & & & \\
\cline { 1 - 2 }
\end{tabular}

Source: Authors

To answer the question of the reliability of the study, we take into consideration Cronbach's alpha. The total number of items in the data set was 26 on the basis that the value of Cronbach's alpha in the table is. 0.861 , which means $86.1 \%$ which is excellent.

\section{Multiple Regression}

Table 4

\begin{tabular}{|l|l|}
\hline \multicolumn{2}{|c|}{ Model Summary } \\
\hline Model & \multicolumn{1}{c|}{$\mathbf{R}$} \\
\hline & $.731^{c}$ \\
\hline & Org_Politics, Stress, \\
\hline
\end{tabular}

Copyright (C) 2021, Journal of Advanced Research in Economics and Administrative Sciences (JAREAS), Under a 
a. Predictors: (Constant), Org_Politics, Stress

b. Dependent Variable: Turnover_Intention

Source: Authors

In Table: 4 the model summary of multiple regressions demonstrates the relationship between the expected value of the dependent variable and the variable considered for the study. All these independent variables mentioned as predictors in the table reveal that the value of $\mathrm{R}$ in this analysis is $73.1 \%$, which reflects the overall fitness of the model.

Table 5

\begin{tabular}{|l|l|}
\hline \multicolumn{2}{|c|}{ ANOVA $^{\mathbf{a}}$} \\
\hline Model & \multicolumn{1}{c|}{ Sig. } \\
\hline d Predictors: (Constant), Org_Politics, Stress & $\mathbf{. 0 0 0}^{\mathbf{d}}$ \\
\hline a. Dependent Variable: Turnover_Intention & \\
\hline d. Predictors: (Constant), Org_Politics, Stress & \\
\hline
\end{tabular}

Source: Authors

Table:5 highlights the health or fitness of the model, as shown in the table the significance level or p-value is 0.000 which is less than 0.05 . This significance value indicates that the research model is fit, and with this model, we can predict the values of dependent variables such as Turnover Intention with the help of independent variables such as Perceived organizational politics, and Job Stress.

\section{Table 6}

\begin{tabular}{|l|l|c|c|c|}
\hline \multicolumn{4}{|c|}{ Coefficient } \\
\hline \multirow{2}{|c|}{ Model } & Standardized Coefficients & Sig. & Collinearity Statistics \\
\hline \multirow{2}{*}{$\mathbf{2}$} & (Constant) & & 0.000 & VIC \\
\cline { 2 - 5 } & Org_Politics & 0.688 & 0.000 & 1.000 \\
\hline \multirow{2}{*}{} & (Constant) & & 0.000 & \\
\cline { 2 - 5 } & Org_Politics & 0.559 & 0.000 & 1.415 \\
\cline { 2 - 5 } & Stress & 0.236 & 0.000 & 1.415 \\
\hline \multirow{2}{*}{3} & (Constant) & & 0.000 & \\
\cline { 2 - 5 } & Org_Politics & 0.457 & 0.000 & 1.879 \\
\cline { 2 - 5 } & Stress & 0.240 & 0.000 & 1.416 \\
\cline { 2 - 5 } & Ext Opportunity & 0.181 & 0.000 & 1.448 \\
\hline \multirow{2}{*}{ a. Dependent Variable: Turnover Intention } & & \\
\hline
\end{tabular}

Source: Authors

Table:6 the coefficient indicates two major values, beta, and p-value. The beta coefficient usually measures the relationship between the dependent variable and the independent variables, while the p-value shows the degree of significance of the variable. In this study we can see all the independent variables i: e perceived organizational politics, and job stress are positive and have a significant relationship with the dependent variable I: e Turnover Intention. In the Coefficient table VIF column, all the independent variables have less than 10 values, which 
shows that this research model has no multi-collinearity. Hence we can say that these research results are not overstated.

\section{Mediating Analysis}

As per mediation study carried out using Andrew F. Hayes' method, which examines the total, direct, and indirect influence of $\mathrm{X}$ on Y.The table 7 shows are the outcomes of the stress as mediation between organizational politics and turnover intention:

Table 7

\begin{tabular}{|l|l|l|l|l|}
\hline \multicolumn{5}{|c|}{ Indirect Effect of X on Y } \\
\hline \multirow{3}{*}{ Total Effect } & Effect & Sd. Error & Lower limit & Upper Limit \\
\cline { 2 - 5 } Direct Effect & .6607 & .0426 & .5768 & .7446 \\
\hline Indirect Effect & .5376 & .0489 & .4414 & .6338 \\
\hline
\end{tabular}

Source: Authors

Table:7 demonstrates the mediating impact of stress on faculty turnover intention in Pakistani universities. The direct effect suggests that corporate politics affects the intent of faculty members by 53.76 percent with standard error. 0489. While stress, as a mediator effect, influences just 18.43 percent of the decision to quit, with a standard error of 0.315 . Moreover, values between 0.681 and 0.1914 suggest that tension mediates the relationships between corporate politics and turnover intention.

\section{Discussion}

This study investigated the role of job pressure in the relationship between organizational politics and turnover intent among faculty members in universities in Pakistan. This study also assessed the impact of politics at the workplace among faculty members in the universities of Pakistan. In this research, we have considered two independent variables such as perceived organizational behavior, and job stress, and one dependent variable such as Turnover intention. Moreover, this research also indicates that organizational politics has stronger relations with job stress (.758), and the correlation between turnover intention and perceived organizational politics is (.688), turnover intention and job stress are (.610). The results of this study suggest that all the independent variables have significant positive effects on the turnover intention of the faculty members, but the impact of perceived organizational politics is more significant than the impact of job stress among faculty members. Workplaces of corporate politics can be challenging as it causes emotional distress among workers. Employees' perceptions of corporate politics will lead to a decrease in job commitment, which will have a detrimental effect on productive work habits and attrition intent (Agarwal, 2016). If the management in universities takes effective measures for organizational politics, and job stress then faculty retention could be effectively improved. Moreover, Job satisfaction and pay levels may have an indirect impact on the rate of attrition of employees via organizational engagement. Findings further suggested that

Copyright (C) 2021, Journal of Advanced Research in Economics and Administrative Sciences (JAREAS), Under a 
an increase in pay level, increase level of employee satisfaction and a higher level of corporate engagement would contribute to lower turnover intentions (C. Lee \& Huang, 2012). According to (Bodla et al., 2014) study indicate a positive relationship between organizational politics and job stress. which demonstrates that an institution's politics may decrease worker efficiency due to job insecurity, work stress, and employees' preferences depending on individual liking and disliking. The majority of job strain is caused within an organization via organizational politics. Therefore, based on the finding, we found out that organizational politics in universities is a very important factor in faculty members of universities. It is also well-known as office politics and workplace politics.

According to Job Demand-Resource model, a job consists of various aspects such as time constraints, tasks, and problems with the physical work environment which influences employee wellbeing, commitment, and motivation in the organization. Considering the JD-R Model Bakker et al. (2007) indicate that the demotivation and stress-inducing potential of job-related requirements such as perceived organizational politics. The relationship between perceived organizational politics and job stress indicates the acceptance of H1. Opinions shared by the workers of the organization about the level of politics in their organizations are significantly linked to detrimental work outcomes, such as anxiety, employment shortages, and turnover intentions, and are negatively linked to the positive outcomes of employee satisfaction, business ethos, work quality and organizational commitment (Chang et al., 2009). H2 was accepted, which states that job stress affects turnover intention. In the turnover framework, exhaustion and stress at work had significant effects and the workplace atmosphere had negative effects. The work environment has had secondary effects on the purpose of attrition by work discomfort and exhaustion (E. Lee \& Jang, 2020). The findings of the study suggest that perceived organizational politics and job stress have a significant and positive impact on turnover intention in faculty members of Universities in Pakistan. H3 was also proved correct and accepted, which means perceived organizational politics affects the turnover intention among faculty members. For instance, High performers and motivated employees lose their engagement towards the job and feel demotivated and insecure in the organization due to politics played by employees. So they start looking for opportunities outside the organization. If management can control and organizational politics, understand the level of stress taken by an employee turnover intention can be changed.

\section{Conclusion and Suggestion}

The findings of this study indicate that organizational politics has a meaningful correlation with stress, which leads to a desire to leave. The findings indicate a positive relationship, which can be supported by other previous research results Using the findings, this study offers a better explanation for the outcomes of workers who may be influenced by politics within universities in Pakistan. Finally, this study provides an understanding of the role of stress in defining the relationship between politics in an organization and intention to leave. This research has both conceptual and operational implications. The theoretical perspective is extended by adding job stress along with perceived turnover-related corporate policies. This study also highlights the

Copyright (C) 2021, Journal of Advanced Research in Economics and Administrative Sciences (JAREAS), Under a 
role of stress and corporate politics in causing workplace uncertainty for the faculty members in universities. There is no previous research that highlights such a relationship between dependent and independent variables.

\section{Limitation and Recommendations}

The sample size of our research was small due to some constraints. Future researchers can use a combination of data collection methods conventional and online questionnaires, along with interviews. The google forms selection method may assist the researcher in reducing study costs and time. It is recommended that future research may consider a large sample size. Faculty members in universities are the main subjects of our research. Even then, it is questionable whether workers of many other professions may face the same challenges and issues that lead to turnover intentions. Future work can therefore evaluate people from diverse business sectors to analyze disparities in the turnover framework. Finally, the future researcher can also consider the influence of Locus of control of employees keeping in mind the perceived organizational politics and turnover intention.

\section{Acknowledgments}

I'd like to take this time to thank correspondence author Prof. Zhang Zengtian for his assistance in this study.

\section{Conflict of Interest}

The authors of the article declare no conflict of interest.

\section{Funding}

This research study was not funded by any institution. The author conducted the study on his own expenses.

\section{References}

Abubakar, R. A., Chauhan, A., \& Kura, K. M. (2014). Relationship between perceived organizational politics, organizational trust, human resource management practices and turnover intention among Nigerian nurses. Management Science Letters, 4(9), 2031-2048. https://doi.org/10.5267/j.msl.2014.8.018

Agarwal, U. A. (2016). Examining perceived organizational politics among Indian managers: Engagement as mediator and locus of control as moderator. International Journal of Organizational Analysis, 24(3), 415-437. https://doi.org/10.1108/IJOA-07-2014-0786

Alliance For Excellent Education. (2014). https://all4ed.org/press/teacher-attrition-costs-unitedstates-up-to-2-2-billion-annually-says-new-alliance-report/

Andrews, M. C., \& Kacmar, K. M. (2001). Discriminating among organizational politics, justice, and support. Journal of Organizational Behavior, 22(4), 347-366.

Copyright (C) 2021, Journal of Advanced Research in Economics and Administrative Sciences (JAREAS), Under a 
https://doi.org/10.1002/job.92

Atinc, G., Darrat, M., Fuller, B., Parker, B. W., Darrat, M., Fuller, B., \& Parker, B. W. (2018).

Perception of Organizational politicsL A Meta Analysis of theoritical Antecedents JSTOR.22(4), 494-513.

Bakker, A. B., Hakanen, J. J., Demerouti, E., \& Xanthopoulou, D. (2007). Job resources boost work engagement, particularly when job demands are high. Journal of Educational Psychology, 99(2), 274-284. https://doi.org/10.1037/0022-0663.99.2.274

Bautista, J. R., Lauria, P. A. S., Contreras, M. C. S., Maranion, M. M. G., Villanueva, H. H., Sumaguingsing, R. C., \& Abeleda, R. D. (2020). Specific stressors relate to nurses' job satisfaction, perceived quality of care, and turnover intention. International Journal of Nursing Practice, 26(1), 1-10. https://doi.org/10.1111/ijn.12774

Bedi, A., \& Schat, A. C. H. (2013). Perceptions of organizational politics: A meta-analysis of its attitudinal, health, and behavioural consequences. Canadian Psychology, 54(4), 246-259. https://doi.org/10.1037/a0034549

Bodla, M., Afza, T., \& Danish, R. (2014). Relationship between organizational politics perceptions and employees' performance: Mediating role of social exchange perceptions. Pakistan Journal of Commerce and Social Sciences (PJCSS), 8(2), 426-444.

Boyas, J., Wind, L. H., \& Kang, S. Y. (2012). Exploring the relationship between employmentbased social capital, job stress, burnout, and intent to leave among child protection workers: An age-based path analysis model. Children and Youth Services Review, 34(1), 50-62. https://doi.org/10.1016/j.childyouth.2011.08.033

Chang, C. H., Rosen, C., \& Levy, P. (2009). The relationship between perceptions of organizational politics and employee attitudes, strain, and behavior: A meta-analytic examination. Academy of Management Journal, 52(4), 779-801. https://doi.org/10.5465/AMJ.2009.43670894

Cohen, S., Kamarck, T., Mermelstein, R. (1983). A global measure of perceived stress. Journal of Health and Social Behavior. Journal of Health and Social Behavior, 24(4), 385-396.

Daskin, M., \& Tezer, M. (2012). Organizational politics and turnover: An empirical research from hospitality industry. 60(3), 273-291.

Dohrmann, S. B., Herttua, K., \& Leppin, A. (2019). Fatigue in ferry shipping employees: The role of work-family conflict and supervisor support. BMC Public Health, 19(1), 1-14. https://doi.org/10.1186/s12889-019-7954-Z

Ferris, G. R., Adams, G., Kolodinsky, R. W., Hochwarter, W. A., \& Ammeter, A. P. (2002). Perceptions of organizational politics: Theory and research directions. Research in MultiLevel Issues, 1, 179-254. https://doi.org/10.1016/S1475-9144(02)01034-2

Ferris, G. R., Frink, D. D., Galang, M. C., Zhou, J., Kacmar, K. M., \& Howard, J. L. (1996). Perceptions of organizational politics: Prediction, stress-related implications, and outcomes. Human Relations, 49(2), 233-265. https://doi.org/10.1177/001872679604900206

Gull, S., \& Zaidi, A. A. (2012). Impact of Organizational Politics on Employees ' Job Satisfaction in the Health Sector of Lahore Pakistan. Interdisciplinary Journal of Contemporary Research In Business, 4(2), 156-170.

Kacmar, K. M., \& Ferris, G. R. (1991). Perceptions of organizational politics scale (POPS):

Copyright (C) 2021, Journal of Advanced Research in Economics and Administrative Sciences (JAREAS), Under a 
Development and construct validation. Educational and Psychological Measurement, 51(1), 193-205. https://doi.org/10.1177/0013164491511019

Karen, C. (2015). Organisational Politics: the Positive \& Negative Sides. European Scientific Journal, 11(1), 1857-7881.

Kaya, N., Aydin, S., \& Ayhan, O. (2016). The Effects of Organizational Politics on Perceived Organizational Justice and Intention to Leave. American Journal of Industrial and Business Management, 06(03), 249-258. https://doi.org/10.4236/ajibm.2016.63022

Kothari, \& Gaurav. (2014). Research Methodology: Methods and Techniques (2nd Editio). New Age International Publisher.

Labrague, L. J., McEnroe-Petitte, D. M., Gloe, D., Tsaras, K., Arteche, D. L., \& Maldia, F. (2017). Organizational politics, nurses' stress, burnout levels, turnover intention and job satisfaction. International Nursing Review, 64(1), 109-116. https://doi.org/10.1111/inr.12347

Landells, E. M., \& Albrecht, S. L. (2019). Perceived organizational politics, engagement, and stress: The mediating influence of meaningful work. Frontiers in Psychology, 10(JULY), 1-12. https://doi.org/10.3389/fpsyg.2019.01612

Lee, C., \& Huang, S. (2012). A Study on Factors Affecting Turnover Intention of Hotel Empolyees. Asian Economic and Financial Review, 2(7), 866-875.

http://search.proquest.com/docview/1417571301?OpenUrlRefId=info:xri/sid:primo\&accou ntid=10371

Lee, E., \& Jang, I. (2020). Nurses' Fatigue, Job Stress, Organizational Culture, and Turnover Intention: A Culture-Work-Health Model. Western Journal of Nursing Research, 42(2), 108-116. https://doi.org/10.1177/0193945919839189

Liu, S., \& Onwuegbuzie, A. J. (2012). Chinese teachers' work stress and their turnover intention. International Journal of Educational Research, 53, 160-170. https://doi.org/10.1016/j.ijer.2012.03.006

M Gbadamosi, O., \& Chinaka Nwosu, J. (2011). Organizational Politics, Turnover Intention and Organizational Commitment as Predictors of Employees' Efficiency and Effectiveness in Academia. Proceedings of the 2011 InSITE Conference, October, 305-314. https://doi.org/10.28945/1461

Meisler, G., \& Vigoda-Gadot, E. (2014). Perceived organizational politics, emotional intelligence and work outcomes: Empirical exploration of direct and indirect effects. Personnel Review, 43(1), 116-135. https://doi.org/10.1108/PR-02-2012-0040

Moore, J. E. (2009). ONE ROAD TO TURNOVER: AN EXAMINATION OF WORK EXHAUSTION IN TECHNOLOGY PROFESSIONALS. Misq, 33(4), 763-783.

Oldenburg, M., Hogan, B., \& Jensen, H. J. (2013). Systematic review of maritime field studies about stress and strain in seafaring. International Archives of Occupational and Environmental Health, 86(1), 1-15. https://doi.org/10.1007/s00420-012-0801-5

Park, J. C., Kim, S., \& Lee, H. (2020). Effect of work-related smartphone use after work on job burnout: Moderating effect of social support and organizational politics. Computers in Human Behavior, 105. https://doi.org/10.1016/j.chb.2019.106194

Rasid, U., Karim, N., \& Rashid, S. (2013). Employee's Perception of Organizational Politics and

Copyright (C) 2021, Journal of Advanced Research in Economics and Administrative Sciences (JAREAS), Under a 
its Relationship with Stress. Asian Journal of Business Management, 5(4), 348-352.

Techera, U. D. (2017). MEASURING AND MANAGING CONSTRUCTION WORKER

FATIGUE. Australian Family Physician, 46(6), 357.

Ullah, R., \& Ahmad, S. Z. (2018). The Effect of Organizational Politics on Job Stress; Mediating Role of Job Satisfaction. Electronic Journal of Business Ethics and Organization Studies, 23(2), 13-23.

Zaniboni, S., Truxillo, D. M., \& Fraccaroli, F. (2013). Differential effects of task variety and skill variety on burnout and turnover intentions for older and younger workers. European Journal of Work and Organizational Psychology, 22(3), 306-317.

https://doi.org/10.1080/1359432X.2013.782288 